\title{
Discussion on the Problems and Countermeasures of Green Accounting Implementation in Enterprises of China in New Era*
}

\author{
Huiqin Tang \\ College of Business and Management \\ Xiamen Huaxia University \\ Xiamen, China 361024 \\ Finance and Audit Information Research Center of Humanities and Social Sciences Base in Fujian Province \\ Xiamen, China 361024
}

\begin{abstract}
At present, the development of green accounting in enterprises of China is still in a positive exploration stage, it is urgent to speed up the construction of a green accounting theory system and development model suitable for China's actual conditions. The results of the evaluation of the current situation of green accounting development of China show that there are some problems in the development of green accounting in China, such as theoretical research, system construction, personnel training, information system, etc., which can be improved from the aspects of promoting the vigorous development of green accounting, laying the foundation for the development of green accounting and block chain supporting information system, etc., which will provide references for the implementation of green accounting in China in new era.
\end{abstract}

Keywords-new era; enterprise; green accounting; problems and countermeasures

\section{INTRODUCTION}

In recent years, the problems of ecological disorder and even ecological crisis have become increasingly prominent due to the blind production and excessive activities of human beings, which has seriously affected and threatened the survival and development of human beings. With the deepening of China's reform and opening up and the continuous and rapid development of the national economy, the problems of high pollution, high energy consumption and high emissions caused by extensive and inefficient enterprise management have caused immeasurable impact on ecological environment of China. On March 5, 2017, Premier Li Keqiang put forward the requirements for winning the blue sky defense war in report on the work of the government. Therefore, the construction of ecological civilization of "beautiful China" and the solution of the ecological environment problems in China have become an urgent task. To explore the establishment of green accounting system and improve the disclosure of green accounting information system in enterprises can not only help enterprises to change the development mode and improve the operating efficiency, but also help enterprises to establish a green

*Fund project: Education and scientific research project for young and middle-aged teachers in Fujian Province (JAS180809). development concept and consciously protect the ecological environment. It can realize the win-win situation of economic development and environmental protection, thus the construction of green accounting has become a trend, and more and more enterprises pay close attention to it.

\section{OVERVIEW OF GREEN ACCOUNTING}

\section{A. Concept of Green Accounting}

Green accounting, also known as environmental accounting, is a new interdisciplinary subject which is composed of accounting and environmental science. It is a kind of professional accounting that uses the traditional accounting method to measure or record the assets, costs, benefits and other accounting elements related to environmental protection. It adopts the basic principles and methods of accounting to recognize, measure and report the consumption of natural resources in the process of production and operation, the impact on the environment and the income and loss caused by the compensation of resources. [1]

\section{B. Development Background of Green Accounting}

Green accounting first came into being in the 1860s during the British Industrial Revolution. At that time, the ecological environment was seriously deteriorated due to the excessive development and utilization of human beings, and the development mode at the expense of the natural environment caused great damage to the ecological environment. In order to alleviate the serious impact of human development on the ecological environment, the research focusing on the harmonious balance of economy and environment has been put on agenda. Scholars use accounting methods to disclose and analyze quantitatively environmental protection, pollution control and other activities.

From 1971 to 1973, F.A. Beams and J.T. Marlin published two papers in Journal of Accounting, namely, Research on Social Cost of Pollution Control Conversion and Pollution of Accounting Issues, which attracted the general attention of accounting theorists. Since then, the research and development 
of green accounting has entered people's vision. In 1992, the United Nations Conference on environment and development held in Rio put forward the concept of green accounting for the first time, which has been generally recognized by the international community.

\section{REVIEWING RELATED LITERATURE}

Since the 1990s, China's theorists began to study green accounting. Due to the limitations of the social and economic development and the level of people's understanding at that time, green accounting has not attracted widespread attention of scholars and the public. After entering the 21st century, there is a growing call for the implementation of green accounting with the increasingly obvious contradiction between environmental deterioration and resource shortage in China. China has begun to explore the theory and practice of green accounting suitable for China's actual conditions.

Li Huiling etc. (2011), put forward countermeasures to promote the implementation of green accounting in China according to the new problems faced by the development of green accounting. [2] Li Xuemin (2011), pointed out the existing problems in the theoretical research, policy support, personnel training and other aspects of green accounting in China based on the analysis of the current situation of green accounting, and proposed to strengthen theoretical research, increase policy support, establish green accounting awareness, train green accounting talents, improve green accounting information disclosure and other perfecting measures. [3] Chen Jinyu (2009) proposed to build green accounting suitable for China's actual conditions by combining market mechanism with government intervention and improving environmental legal system. [4] Cui Junping etc. (2015), analyzed the existing problems of green accounting work under the new normal of economy according to the characteristics of the new normal of China's economy, and put forward the improvement measures of management system, information construction and the quality of employees. [5] Jiang Leping (2018) believed that block chain technology can solve the bottleneck problem affecting the green accounting information system and effectively promote the promotion and application of macro green accounting. [6] Wang Xiaohong etc. (2018) [7], studied the combination of green accounting and big data, and put forward suggestions on building a green accounting system with Chinese characteristics and formulating green accounting regulations.

From the above research, scholars focus on the analysis of the problems and reasons of the development of green accounting in China, and raise the improvement direction and suggestions combined with China's actual conditions and the actual situation of enterprises. All of these provide a good theoretical guidance and practical reference for the development of green accounting in enterprises of China. However, scholars mainly start from the perspective of traditional financial management when they put forward suggestions for improvement, but there are relatively few researches from the perspective of new financial management represented by block chain technology and financial sharing mode. Therefore, if the traditional financial management is taken as the main way and the new financial management is used as the auxiliary way in the research on the development of green accounting of China, it will provide new ideas and strategies for improving the development of green accounting in China.

\section{PROBlEMS AND COUNTERMEASURES OF GREEN ACCOUNTING DEVELOPMENT IN ENTERPRISES OF CHINA}

\section{A. Overall Evaluation of the Development of Green Accounting in China}

1) Development of green accounting in China: The development of green accounting in China is gradually developing with the deepening of reform and opening up. The development of green accounting in China can be divided into three stages: embryonic stage, initial stage and exploration stage according to the different developing degree. In September 1979, with the promulgation and implementation of the first Environmental Protection Law in China, the law stipulates that any unit must issue an environmental impact report when it is constructing or renovating or expanding a project, which marks that the development of green accounting in China has entered the embryonic stage. After that, the theoretical research and practice of green accounting in China began slowly with the reference and learning of western green accounting research results.

2) The urgency for enterprises to speed up the development of green accounting: At present, China's ecological environment is facing the basic situation of "overall deterioration and partial improvement", and it is under the triple pressure of population, industrialization and market. At the same time, China's ecological governance capacity is far behind the speed of destruction, the ecological deficit is gradually expanding, and the construction of ecological civilization has a long way to go. From the perspective of total resources, China is a big country, but from the perspective of per capita resources, China's current situation is significantly lower than the world average. Taking the share of fresh water resources as an example, China's per capita fresh water resources is only 2,200 cubic meters, only 1 / 4 of the world average level [8].

At present, many enterprises in China still adopt the extensive economic development mode at the expense of environment and by means of wasting resources. As a result, the economic benefits per unit energy consumption of enterprises in China are far lower than the average level of enterprises in developed countries in Europe and America. The current simple and extensive business model is difficult to be maintained with the resource scarcity and ecology deterioration in China. Therefore, the research and application of green accounting in enterprises and the quantitative evaluation of the indicators related to resource consumption and environmental protection in production and operation will not only help to establish the awareness of environmental protection and the concept of resource conservation, but also help enterprises to improve production efficiency and perfect production management. In addition, in order to accelerate the development of green accounting, enterprises can also promote 
accounting, nor have they come into contact with the relevant knowledge of green accounting, let alone support and promote the development of green accounting.

4) Accounting talents are insufficient, talent training lags behind: From the perspective of the professional quality of green accountants, green accountants should not only master the professional knowledge of accounting, but also be familiar with the interdisciplinary knowledge of green economy, environmental protection and so on. They should have strong professional quality and high moral quality. Although the accounting industry of China has enough talent reserve, the current qualified green accounting talent is still relatively short due to the high quality requirements of green accounting for employees. At the same time, due to the insufficient guidance of government policies and the weak comprehensive strength of training institutions, the talent cultivation of green accounting industry in China is relatively lagging behind, and the contradiction between supply and demand of green accounting talents is more prominent. In addition, although the requirements to quality of green accounting personnel is high and the work is difficult, their salary and treatment are basically the same as that of ordinary accounting personnel, which cannot fully mobilize their work enthusiasm and affect the development of green accounting to a certain extent.

5) Disclosure system is lax, and information disclosure is incomplete: At present, there is no clear unified disclosure standard for environmental information disclosure in China. There is no uniform way for enterprises to disclose environmental information. The disclosure methods and contents are different. Most of them are only brief introduction or overall description. It is difficult to provide decisionmaking reference for other enterprises or government agencies. According to the analysis of the financial statements of 118 enterprises, the results show that although more than $70 \%$ of the enterprises disclose environmental protection information, most of these enterprises simply describe environmental protection information in the annotation to the financial statements, and the disclosure standards are different and the disclosure contents are different.[9] The incomplete and inaccurate environmental protection information disclosed by these enterprises is not only easy to confuse or even mislead the information users, but also not conducive to the guidance and supervision of government agencies on green accounting.

6) Information transmission is limited, and information supervision is deficiency: The collection of green accounting information in China is mainly done by enterprises themselves for a long time. Due to the difference of information recording and transmission technology, different information systems, different transmission standards and different data interfaces among different enterprises, it not only seriously affects the efficiency of green accounting information transmission and submission, but also brings a lot of workload to the later data collection. The limited transmission of green accounting information will lead to the great discount of economic value and social utility of green accounting information disclosure. of the public in China have not heard the concept of green 
On one hand, due to the lack of mandatory provisions and no impact of disclosure, the enthusiasm of enterprise information disclosure is not high, and the awareness of internal control and audit of green accounting information quality has not been established. On the other hand, the disclosure requirements of green accounting have not been raised to accounting standards, and the government and industry associations lack effective supervision of green accounting information.

\section{Suggestions on Improving the Implementation of Green Accounting in Enterprises}

1) Concept and theory work together to lay the foundation for the development of green accounting

a) Setting up green idea, and strengthening knowledge popularization: Protecting ecological environment is to protect productivity, and improving ecological environment is to develop productivity. Only when the whole society attaches great importance to the construction of ecological civilization, closely combines the development of green accounting with the effective protection of the environment, and ensures that the publics have a sense of happiness, enterprises have a sense of gain, and employees have a sense of achievement in the process of the development of green accounting, can China's green accounting development enter a new mode of sound development and innovative development. In addition, in order to create a good atmosphere for the development of green accounting, it is necessary to strengthen the popularization of green accounting knowledge, and let accounting personnel expect a good prospect and enterprises taste a sweet spot in the promotion and application.

b) Strengthening theoretical research, and improving accounting standards: As a new frontier subject, it is a must to pay attention to theoretical research and put accounting theoretical research in an important position if green accounting wants to develop greatly. On one hand, it is suggested to increase the translation and introduction of foreign green accounting theories, boldly learn from the advanced experience of European and American countries, and actively explore the theoretical system of green accounting with Chinese characteristics. On the other hand, it is necessary to strengthen the cross integration with other disciplines and related industries, and inject new elements and bring new achievements into the development of green accounting in China on the basis of summing up the successful experience of ecological civilization construction, so as to realize the mutual penetration development of accounting and environmental protection theories. In addition, in the process of strengthening the theoretical research, it is recommended to not only pay attention to improve the current accounting standards, but also speed up the standardization of the statement requirements of green accounting information disclosure; not only let the green accounting theory play a role, but also let the green accounting work smoothly.

2) Policies and talents go hand in hand to promote the vigorous development of green accounting a) Increasing policy support, and matching with reward and punishment measures: In order to actively build a "resource-saving and environment-friendly" society, the government should adhere to the principle of "green", refine and formulate green accounting policies, and improve some clauses that are not conducive to environmental protection and resource conservation. Meanwhile, the measurement method of green accounting should be included in the corresponding accounting laws and regulations as soon as possible, so that there are laws to be abided by and the laws are surely strictly observed. In order to encourage enterprises to disclose environmental accounting information, the government should speed up the introduction of reward and punishment policies for information disclosure, give tax incentives and other rewards to those who disclose truthfully according to law, and impose severe penalties on those who conceal or falsely disclose, and implement zero tolerance for illegal acts that damage the environment, so as to eliminate the fluke psychology of enterprises not disclosing environmental information. In addition, in the business activities of lending to enterprises, financial institutions should strengthen the examination of loan qualification in terms of environmental protection and resource conservation.

b) Improving personnel training, and promoting comprehensive quality: In order to improve and perfect the internal control system of green accounting, enterprises should set up independent green accounting posts, which is specialized in green accounting related work and focusing on solving related green accounting problems. Meanwhile, at the same time of clarifying the division of green accounting posts, it is suggested to carry out regular rotation of green accounting personnel in a planned and step-by-step way to help them fully understand the situation and get familiar with business. In order to speed up the cultivation of "compound" green accounting talents, enterprises should raise the entry threshold, strengthen professional ethics education, pay attention to the cultivation of professional quality and moral quality, and ensure that green accounting personnel are qualified in business and professional ethics.

3) Block chain embeds information system to help green accounting innovation and development: The rapid development of enterprises will raise higher requirements for the construction of green accounting information with the continuous development of green accounting. Enterprises should increase investment in capital and technology, and establish a green accounting information platform in line with their own characteristics. At the same time, in view of the problems of limited transmission and insufficient sharing of green accounting information system, enterprises should actively explore the effective connection between new technology and green accounting information system. Among them, block chain technology has attracted much attention in the industry due to its characteristics of decentralization, distributed storage, cryptography and so on. If the block chain technology can be explored and embedded in green accounting information system, it will effectively promote the 
[4] Chen Jinyu. Rational Thinking on Construction of Environmental Accounting in China [J]. Ecological Economy, 2006 (01): 47-49 (in Chinese)

of China.

a) Block chain technology helps green accounting information system: With the integrated application of block chain technology and environmental protection Internet of things, enterprises can embed block chain technology into green accounting information system, and improve the data collection, summary, transmission and analysis process of green accounting information system. Firstly, the encryption technology of the block chain can not only ensure that the green accounting information on the block chain is open, transparent and tamper-resistant, but also ensure that every user's account identity is strictly authorized and highly encrypted. Secondly, the distributed storage technology of block chain can not only realize the instant collection and upload of information, but also prevent data loss and ensure the storage security.

b) Block chain technology helps to realize information sharing of green accounting: After the enterprise embeds the block chain technology into the green accounting information system, it can join with the public chain led by the government or the alliance chain led by the industry, so as to realize the seamless integration between the green accounting information of the enterprise and the industry, and share with the society in an all-round way. Under the mode of public chain or alliance chain, enterprises choose appropriate information disclosure forms according to their own information authorization, and obtain corresponding green accounting information according to their own needs. This not only protects the privacy of enterprise environmental information, but also provides an open and unified platform for sharing green accounting information of enterprises.

\section{CONCLUSION}

At present, China's environmental carrying capacity has reached or is close to the upper limit. It is an urgent task to accelerate the new way of green low-carbon circular development and the construction of a green accounting management system with Chinese characteristics. It is necessary to take many measures from the aspects of theoretical research, system construction, personnel training, information system and so on to solve the difficulty that how to solve the problems existing in the development of green accounting in China. It is recommended to boldly try to introduce cutting-edge technologies represented by block chain technology so as to effectively promote the vigorous development of green accounting in enterprises of China.

\section{REFERENCES}

[1] Lu Guolian. Theory and System Construction of Green Accounting [J]. Western Accounting, 2011 (01): 22-25 (in Chinese)

[2] Li Huiling, Zhang Xueqin. Obstacles Analysis and Research on Countermeasures on Implementation of Environmental Accounting [J]. Friends of Accounting, 2011 (20): 50-51(in Chinese)

[3] Li Xuemin. Discussion on Green Accounting in New Environment [J]. Market Modernization, 2017 (01): 151-153 (in Chinese)
[5] Cui Junping, Lu Mei. Discussion on Green Accounting under New Normal of Economy [J]. China Business Theory, 2015 (29): 19-22 (in

[6] Jiang Leping. Optimization and Integration of Environmental Accounting Information System from the Perspective of Block Chain [J]. Journal of Finance \& Accounting, 2018 (19): 52-56 (in Chinese)

[7] Wang Xiaohong, Tian Mi, Meng Yali. Opportunities and Challenges of Environmental Management Accounting in Era of Big Data [J]. Friends of Accounting, 2019 (01): 55-59 (in Chinese)

[8] Bi Xianyun. Problems and Solutions of Water Resources Planning [J]. Heilongjiang Science and Technology Information, 2013 (31): 231 (in Chinese)

[9] Jin Youliang, Zhou Zhenjuan. Discussion on Problems and Countermeasures on Implementation of Green Accounting in Enterprises of China [J]. Science and Technology Management Research, 2013, 33 (20): 222-225 (in Chinese) Chinese) 